Jurnal Belantara [JBL] Vol. 2, No. 1, Maret 2019 (35-42)

DOI: https://doi.org/10.29303/jbl.v2i1.93

\title{
DISTRIBUSI MONYET EKOR PANJANG (Macaca fascicularis) DI TAMAN NASIONAL WAY KAMBAS
}

\author{
Distribution Of Long Tailed Macaque In Way Kambas National Park
}

\author{
Nidya Astrida Ziyus, Agus Setiawan, Bainah Sari Dewi, Sugeng Prayitno Harianto
}

Jurusan Kehutanan, Fakultas Pertanian, Universitas Lampung

Jl. Prof. Dr. Soemantri Brojonegoro No. 1, Bandar Lampung

Email: Nidya.astrida27@gmail.com

\begin{abstract}
Long-tailed macaque (Macaca fascicularis) is one of the forest-dwelling animals. Longtailed monkeys can be found along the road that connects the green signpost with elephant training center. The aim of research to determine the spread of long-tailed monkeys in the area. The research methods used Concentration Count on points discovery of groups of long-tailed monkeys. An observation method used to determine the area of long-tailed monkeys move is done by taking the coordinates of the GPS based outer canopy that is used to move. Habitat conditions are determined using the Rapid Assessment. The results obtained in such a location that there are five groups of long-tailed monkeys who are geographically separated from each other. Fifth habitat conditions are relatively similar groups dominated by rosewood and main feed jeluak, hibiscus and islands. Three groups of five of the group activities occur near Entrance PLG. It shows that the group is influenced by tourist activity. Two other groups are in the natural habitat conditions.
\end{abstract}

Keywords: long-tailed monkeys, distribution, Way Kambas National Park.

\begin{abstract}
ABSTRAK
Monyet ekor panjang (Macaca fascicularis) merupakan salah satu satwa penghuni hutan. Monyet ekor panjang dapat dijumpai di sepanjang jalan yang menghubungkan Plang Hijau dengan PLG. Tujuan penelitian untuk mengetahui penyebaran monyet ekor panjang di areal tersebut. Penelitian menggunakan metode Concentration Count pada titik-titik ditemukannya kelompok monyet ekor panjang. Metode observasi digunakan untuk menentukan luas areal beraktivitas monyet ekor panjang dilakukan dengan pengambilan titik koordinat GPS berdasarkan tajuk terluar yang digunakan untuk beraktivitas. Kondisi habitat ditentukan dengan menggunakan metode Rapid Assessment. Hasil penelitian yang diperoleh bahwa di lokasi tersebut terdapat lima kelompok monyet ekor panjang yang secara geografis terpisah satu sama lain. Kondisi habitat kelima kelompok relatif sama didominasi oleh sonokeling dan pakan utama yaitu jeluak, waru dan pulai. Tiga kelompok dari lima kelompok tersebut aktivitasnya terjadi dekat dengan Pintu Masuk PLG. Hal itu menunjukkan bahwa kelompok tersebut dipengaruhi oleh aktivitas wisatawan. Dua kelompok lainnya berada pada kondisi habitat yang alami.
\end{abstract}

Kata Kunci: Monyet Ekor Panjang, Distribusi, Taman Nasional Way Kambas. 


\section{PENDAHULUAN}

Monyet ekor panjang merupakan salah satu satwa penghuni hutan yang memiliki arti penting dalam kehidupan di alam. Pada habitatnya monyet ekor panjang dapat menjalankan fungsi ekologisnya, yaitu sebagai pemencar biji tanaman buah (pemencar biji pertama) yang penting bagi konservasi jenis tumbuhan dan sebagai pengendali populasi serangga dengan cara memangsanya (Seponada dan Firman, 2010). Monyet ekor panjang dalam menjalankan fungsi ekologisnya dibantu oleh dung beetle sebagai pemencar biji tanaman buah kedua (Dewi, 2015).

Monyet ekor panjang dapat dijumpai di sepanjang jalan yang menghubungkan Plang Hijau dengan PLG. Plang Hijau dan sekitarnya, terletak di pintu gerbang masuk utama Taman Nasional Way Kambas (TNWK), dengan aksesibilitas yang dapat dilalui kendaraan besar seperti bis ukuran besar, sepeda dan sepeda motor. Taman Nasional Way Kambas dengan kekayaan hayati dan non hayati yang dimilikinya merupakan potensi yang sangat besar untuk dikembangkan menjadi objek ekowisata geri. Beberapa lokasi telah menjadi icon wisata yaitu Pusat Latihan Gajah (BTNWK, 2016). Pusat Latihan Gajah mengundang banyak wisatawan untuk datang ke PLG untuk berwisata. Jumlah wisatawan yang masuk menggunakan kendaraan yang melintasi jalan yang menghubungkan Plang Hijau dengan PLG cukup banyak.

Kebiasaan wisatawan memberikan pakan saat melintasi jalur ini membuat perilaku monyet berubah yang dapat mempengaruhi penyebaran monyet ekor panjang. Perilaku manusia walaupun tidak secara langsung mengganggu monyet ekor panjang, akan tetapi mengurangi keleluasaan monyet ekor panjang untuk beraktifitas (Febrianti \& Dewi, 2010). Penelitian ini menjadi penting untuk mengetahui perilaku serta penyebaran monyet ekor panjang. Tujuan penelitian ini adalah untuk mengetahui penyebaran monyet ekor panjang di TNWK.

\section{METODE}

Penelitian dilaksanakan pada bulan Maret-Mei 2018 di sepanjang jalan yang menghubungkan Plang Hijau dengan PLG TNWK, Kabupaten Lampung Timur, Provinsi Lampung. Data yang dikumpulkan meliputi data primer dan data sekunder. Data primer merupakan data yang secara langsung diambil dari area pengamatan meliputi jumlah kelompok dan penyebaran monyet ekor panjang. Data tersebut dikumpulkkan dengan menggunakan metode area terkonsentrasi (Concentration Count) yaitu pengamatan dilaksanakan terkonsentrasi pada satu titik yang diduga memiliki intensitas perjumpaan yang tinggi terhadap satwa. Kondisi habitat dikumpulkan dengan menggunakan metode rapid assement. Metode observasi digunakan untuk menentukan luas areal beraktivitas monyet ekor panjang dilakukan dengan pengambilan titik koordinat GPS berdasarkan tajuk terluar yang digunakan untuk beraktivitas.

Data yang diperoleh dianalisi secara deskriptif disertai dengan table dan grafik, Data sekunder meliputi kondisi umum lokasi penelitian, jenis pakan monyet ekor panjang dan data pendukung lainnya di TNWK. 


\section{HASIL dan PEMBAHASAN}

\section{A. Habitat Monyet Ekor Panjang}

kondisi habitat secara umum monyet ekor panjang meliputi pelindung, ruang, air, ketersedian pakan, dan vegetasi. . Jenis-jenis pohon yang sering ditemukanpada setiap titik perjumpaan dengan monyet ekor panjang dapat dilihat pada Tabel 1

Tabel 1. Jenis-jenis pohon inang pada penelitian distribusi monyet ekor panjang (Macaca fascicularis) di TNWK bulan Maret-Mei 2018

Table 1. Host tree species in the study of the distribution of long-tailed monkeys (Macaca fascicularis) in the TNWK in March - May 2018

\begin{tabular}{llllllllc}
\hline No & Nama Lokal & Nama Latin & A & B & C & D & E & Jumlah \\
\hline 1. & Sonokeling & Dalbergia latifolia & 3 & 3 & 3 & 2 & - & 11 \\
2. & Mahoni & Swietenia mahagoni & 1 & - & - & - & - & 1 \\
3. & Angsana & Pterocarpus indicus & 1 & - & 1 & 4 & 2 & 8 \\
4. & Mindi & Melia azedarach & 2 & 4 & 1 & - & 1 & 8 \\
5. & Pulai * & Alstonia scholaris & - & - & - & - & 5 & 5 \\
6. & Jeluak * & Microcos tomentosa & - & - & - & - & 3 & 3 \\
7. & Kayu Manis & Cinnamomum burmanni & - & - & - & - & 1 & 1 \\
8. & Waru * & Hibiscus tiliaceus & - & - & - & - & 3 & 3 \\
\hline & Total & & & & & & & $\mathbf{4 0}$ \\
\hline
\end{tabular}

Keterangan *: Pohon yang daun, buah, biji, menjadi pakan monyet ekor panjang.

Berdasarkanhasil penelitian,, terdapat 8 jenis pohon yang sering dikunjungi Macaca fascicularis sebagai pohon inang atau pohon yang sering dipanjat serta dijadikan sebagai tempat bermain. Jenis-jenis tumbuhan tersebut antara lain sonokeling, mahoni, angsana, mindi, pulai, jeluak, kayu manis, waru. Menurut Risdiyansyah et al. (2014) dan Santoso (1996), bahwa jenis pohon yang tergolong sering digunakan sebagai sumber pakan monyet ekor panjang yaitu waru (Hibiscus tiliaceus). Bagian yang dimakan oleh monyet ekor panjang yaitu daun, bunga, dan buah. Sesuai dengan Zairina et al. (2015) menyatakan bahwa daun, bunga, dan buah pulai, juga sering menjadi pakan monyet ekor panjang.

Kelompok-kelompok monyet menggunakan vegetasi di sepanjang jalan yang menghubungkan Plang Hijau dengan PLG sebagai tempat atau ruang bermain, sedangkan habitat yang dijadikan pohon tidur kelompok monyet ekor panjang ini berada pada bagian lebih dalam dari jalur yang bervegetasi. Monyet ekor panjang pada penelitian ini keluar dari habitatnya sekitar pukul 09.00 dan bermunculan pada vegetasi yang dijadikan tempat atau ruang bermain sampai pukul 14.00 WIB dengan aktivitas bermain/ berpindah/ bergelantungan/ makan. Menurut penelitian Santoso (1996), monyet ekor panjang keluar pada pukul 10.00 15.00 dengan aktivitas utama yaitu istirahat.

\section{B. Penyebaran Monyet ekor Panjang}

Berdasarkan hasil penelitian yang telah dilakukan terdapat lima kelompok monyet ekor panjang dengan jumlah individu yang ditemukan pada titik penelitian A sebanyak 16 ekor, pada titik penelitian B sebanyak 13 ekor, pada titik penelitian $\mathrm{C}$ sebanyak 8 ekor, pada titik penelitian D sebanyak 17 ekor, dan titik penelitian E sebanyak 20 ekor, sehingga jumlah keseluruhan 
individu dari titik $\mathrm{A}+\mathrm{B}+\mathrm{C}+\mathrm{D}+\mathrm{E}$ adalah 74 ekor. Penyebaran monyet ekor panjang yaitu titik kelompok $A$ terletak paling dekat dengan pintu masuk PLG. Titik kelompok B terletak diantara kelompok $A$ dan $C$ sebelum pintu masuk PLG. Titik kelompok $C$ terletak dekat dengan kelompok B. Titik kelompok D terletak di depan Resort Bagian III Kuala Penet. Titik kelompok E terletak dekat dengan sumber air sebelum jalan pintu masuk proyek. Peta penyebaran monyet ekor panjang dapat dilihat pada Gambar 1.

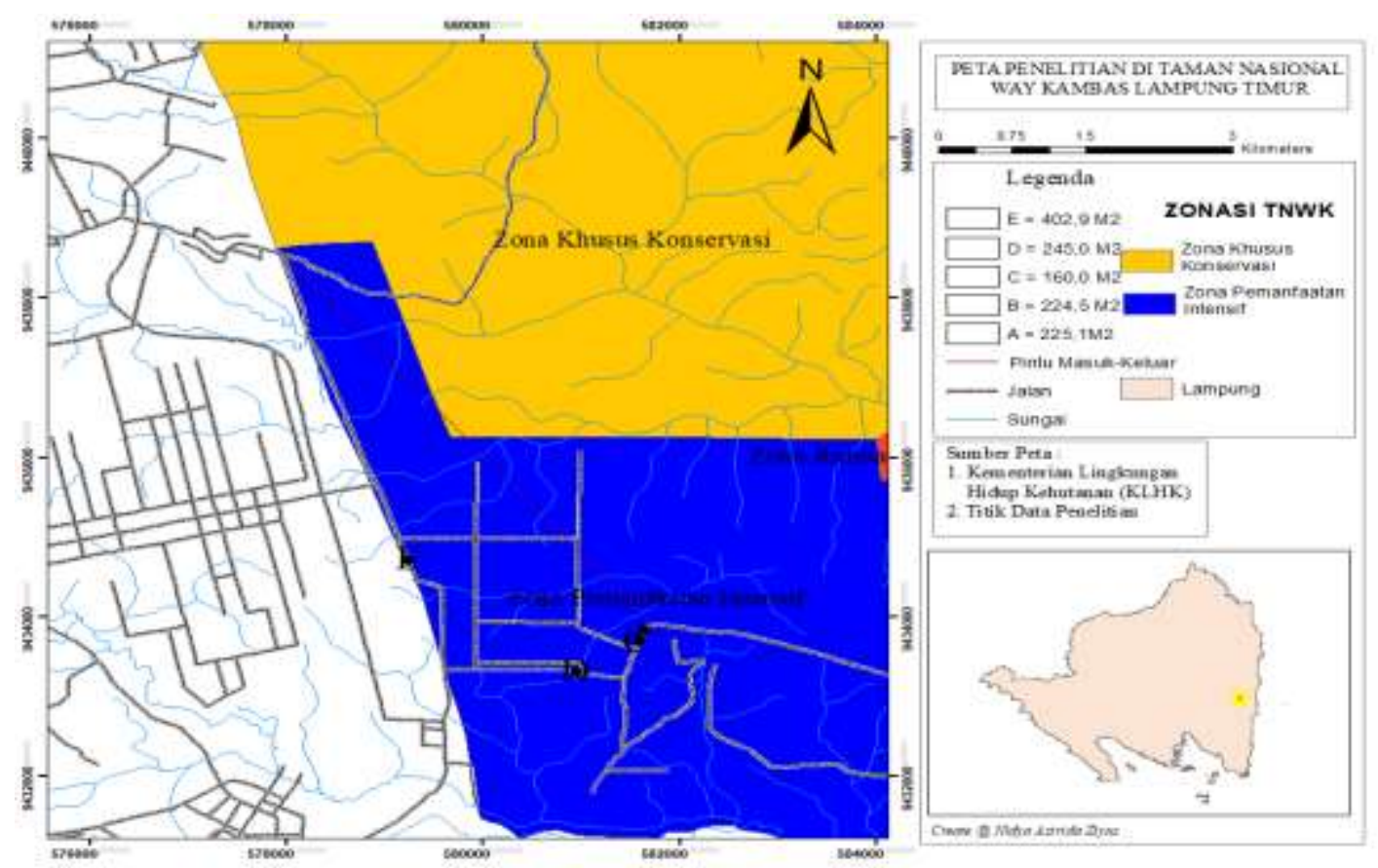

Gambar 1. Peta Penyebaran pada penelitian distribusi monyet ekor panjang

(Macaca fascicularis) di TNWK bulan Maret-Mei 2018 dengan skala 1:75.000.

Figure 1. Spread map in the study of distribution of long-tailed monkeys (Macaca fascicularis) in the TNWK in March - May 2018 with a scale of 1: 75,000.

Berdasarkan Gambar 1 menunjukkan bahwa monyet ekor panjang paling banyak tersebar dekat pintu masuk Pusat Latihan Gajah (PLG). Hal ini disebabkan karena wisatawan yang berkunjung ke PLG mempengaruhi penyebaran monyet ekor panjang. Berdasarkan pengamatan selama 10 hari, monyet ekor panjang kelompok $A, B, C$ ditemukan dekat dengan pintu PLG sedangkan dua kelompok yang lain seperti kelompok $D$ dan $E$ berada dekat dengan Resort Bagian III Kuala Penet. Luasan ruang dan tempat bermain monyet ekor panjang pada setiap kelompok yaitu kelompok A luasannya yaitu $225,1 \mathrm{~m}^{2}$, Kelompok B luasannya yaitu 224,5 $\mathrm{m}^{2}$, kelompok C luasannya yaitu $160 \mathrm{~m}^{2}$, kelompok D luasannya yaitu $245 \mathrm{~m}^{2}$, kelompok $E$ luasannya yaitu $402,9 \mathrm{~m}^{2}$. Kelompok $\mathrm{E}$ memiliki luasan daerah bermain lebih besar daripada kelompok yang lainnya. Hal itu disebabkan karena jumlah jenis tanaman yang beragam dan diantara jenis tersebut terdapat pakan monyet ekor panjang sehingga dapat mempengaruhi jumlah individu monyer ekor panjang. Keterkaitan jenis pakan, jumlah individu dan luas tempat bermain dapat dilihat pada Tabel 2. 
Tabel 2. Keterkaitan jenis pakan, jumlah individu dan luas tempat bermain pada penelitian distribusi monyet ekor panjang (Macaca fascicularis) di TNWK bulan Maret-Mei 2018

Table 2. Linkage of feed types, number of individuals and area of play in the study of the distribution of long-tailed monkeys (Macaca fascicularis) in the TNWK in March - May 2018

\begin{tabular}{|c|c|c|c|c|c|}
\hline Lokasi & $\begin{array}{l}\text { Jumlah } \\
\text { Jenis } \\
\text { Tanaman }\end{array}$ & $\begin{array}{l}\text { Jumlah } \\
\text { Jenis } \\
\text { Pakan }\end{array}$ & $\begin{array}{l}\text { Luas } \\
\text { tempat } \\
\text { bermain } \\
\left(\mathrm{m}^{2}\right)\end{array}$ & $\begin{array}{l}\text { Jumlah } \\
\text { Individu }\end{array}$ & Keterangan \\
\hline A & 4 & - & 225,1 & 16 & $\begin{array}{l}\text { Dekat dengan } \\
\text { pintu PLG }\end{array}$ \\
\hline$B$ & 2 & - & 224,5 & 13 & $\begin{array}{l}\text { Dekat dengan } \\
\text { pintu PLG }\end{array}$ \\
\hline C & 3 & - & 160,0 & 8 & $\begin{array}{l}\text { Dekat dengan } \\
\text { pintu PLG }\end{array}$ \\
\hline D & 2 & - & 245,0 & 17 & $\begin{array}{l}\text { Di depan Resort } \\
\text { Bagian III Kuala } \\
\text { Penet }\end{array}$ \\
\hline$E$ & 6 & 3 & 402,9 & 20 & $\begin{array}{l}\text { Di dekat sumber } \\
\text { air sebelum Pintu } \\
\text { Masuk Jalan } \\
\text { Proyek }\end{array}$ \\
\hline
\end{tabular}

Berdasarkan Tabel 2 dapat diketahui bahwa jumlah individu kelompok C yaitu 8 ekor. Kelompok $\mathrm{C}$ memiliki jumlah individu paling sedikit diduga karena hasil pemecahan kelompok (segregasi). Monyet ekor panjang akan keluar dari kelompok dan membentuk kelompok baru. Menurut penelitian Zairina et al. (2015) monyet ekor panjang memiliki perilaku yang selalu membentuk kelompok baru yang lebih kecil. Hal ini menyebabkan tersebarnya kelompokkelompok primata ini ke daerah yang lebih luas. Persebaran monyet ekor panjang dapat dilihat pada Gambar 2.

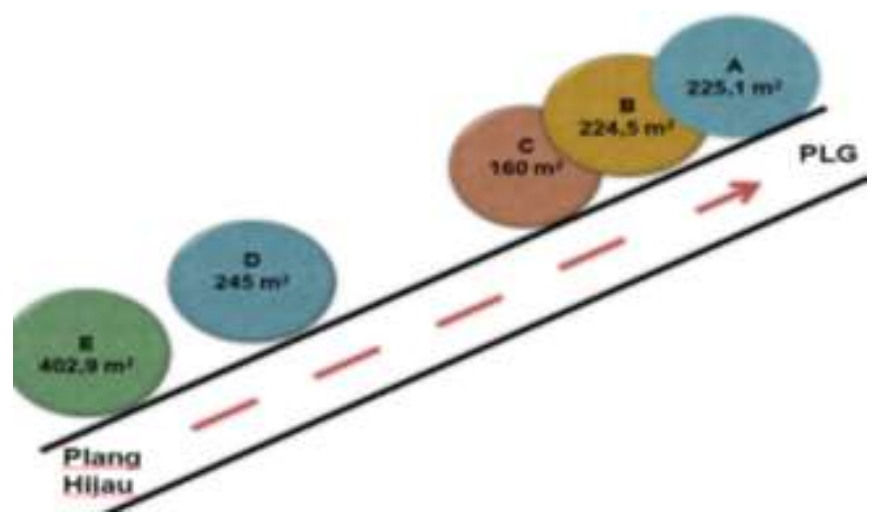

Gambar 2. Persebaran monyet ekor panjang pada penelitian distribusi monyet ekor panjang (Macaca fascicularis) di TNWK bulan Maret-Mei 2018

Figure 2. Distribution of long-tailed monkeys in the study the distribution of long-tailed macaque (Macaca fascicularis) in TNWK March-May 2018 
Kelompok E merupakan kelompok yang memiliki jumlah individu paling banyak yaitu 20 ekor. Monyet ekor panjang berada pada titik tersebut karena pada lokasi tersebut terdapat sumber air dan tempat beraktivitas yang luas yang terdiri dari 6 jenis tanaman. Tiga jenis dari tanaman yang ada tersebut merupakan pakan dari monyet ekor panjang. Oleh sebab itu, jumlah individu monyet ekor panjang dipengaruhi oleh keberagaman jenis tanaman pakan, luasan wilayah berlindung dan tempat beraktivitas. t Hal ini sesuai Sembiring et al. (2016) menyatakan bahwa persebaran kelompok monyet ekor panjang dipengaruhi oleh keberadaan sumber air, sumber pakan, manusia dan satwa lain.

Selain sumber air, pakan dan tempat berlindung, ketiadaan predator dan pesaing di titik E juga mempengaruhi banyak individu di lokasi tersebut. Menurut penelitian Fakhri et al. (2012) bahwa berkumpulnya individu-individu pada suatu tempat tidak selalu menunjukkan tempat tersebut memiliki kondisi lingkungan yang optimal serta jumlah pakan melimpah, tetapi juga dapat disebabkan tidak ada predator dan pesaing. Kelompok $\mathrm{E}$ adalah kelompok yang tidak dipengaruhi aktivitas wisatawan karena titik kelompok $E$ berada jauh dari aktivitas wisatawan di PLG. Selain itu di lokasi tersebut terdapat 3 jenis pohon yaitu.. yang merupakan pakan dari monyet ekor panjang serta tempat beraktivitas yang luas.

Kelompok A, B, C merupakan kelompok yang tersebar dekat dengan aktivitas wisatawan yaitu dekat denganpintu masuk PLG. Kelompok ini memiliki perilaku yang telah berubah. Perubahan tersebut diduga dipengaruhi oleh aktivitas wisatawan. Wisatawan yang ingin berkunjung ke PLG akan melintasi Plang Hijau, ditempat tersebut banyak penjual yang menjajakan pakan untuk diberikan kepada monyet ekor panjang. Pada saat wisatawan melintasi jalur tersebut maka satu persatu kelompok akan bermunculan untuk meminta pakan dari wisatawan. Hal ini sudah terbiasa terjadi karena wisatawan selalu memberikan pakan pada monyet ekor panjang. Kebiasaan wisatawan memberikan pakan menyebabkan monyet ekor panjang sudah terbiasa dengan kehadiran manusia. Menurut penelitian Hidayat (2016) pada habitat alami, satwa akan menganggap kehadiran manusia sebagai ancaman atau setidak-tidaknya merupakan sesuatu yang perlu diwaspadai. Berdasarkan hasil penelitian, hal tersebut berbeda dengan hasil yang diperoleh, monyet ekor panjang akan mendekati manusia (wisatawan) untuk meminta makanan. Pada lokasi ketiga, tidak terdapat jenis pakan monyet ekor panjang yang dapat dijadikan makanan.

Pada titik ini hanya terdapat jenis-jenis pohon yang dijadikan tempat berlindung, sehingga sumber pakan kelompok-kelompok tersebut tergantung pada pakan yang diberikan wisatawan. Berdasarkan hasil penelitian, monyet ekor panjang akan lebih banyak keluar ke jalan apabila ada kendaraan roda empat yang melintas atau berhenti, dibandingkan motor dan sepeda. Wisatawan yang mengendarai kendaraan roda empat sering member pakan kepada monyet ekor panjang. Hal itu menyebabkan monyet ekor panjang terbiasa dengan kehadiran manusia.

\section{Perilaku Monyet Ekor Panjang}

Perbedaan antara kelompok monyet ekor panjang satu dengan kelompok yang lainnya ditandai yaitu setiap masing-masing kelompok memiliki 1 jantan alfa. Menurut Pramudya et al. (2015) pemimpin kelompok terlihat lebih mencolok dari anggota kelompok lainnya, dengan badan yang lebih besar dan warna rambut yang lebih gelap. Pemimpin kelompok tersebut 
biasa disebut jantan alfa. Jantan alfa akan menanggapi keberadaan predator potensial dengan mengeluarkan suara sebagai tanda bahaya dan membuat anggota kelompok bersembunyi di tempat dengan vegetasi yang rapat.

Jantan alfa juga memiliki sikap yang agresif. Jantan alfa akan menyerang apabila anggota kelompoknya merasa terancam. Jantan alfa juga akan merebut makanan yang dibawa oleh wisatawan apabila wisatawan tidak memberikan pakan tersebut. Monyet ekor panjang akan menyerang dengan cara melompat ke arah pengunjung untuk mengambil pakan tersebut. Menurut Djuwantoko et al. (2008) monyet jantan dewasa menunjukkan perilaku agresif yang paling intensif dibanding betina dan kelompok umur yang lebih muda.

Berdasarkan hasil penelitian, monyet ekor panjang di sepanjang jalan yang menghubungkan Plang Hijau dengan PLG, individu-individu monyet ekor panjang berpindahpindah dari satu tempat ke tempat lainnya yaitu dari lokasi atau titik yang berada di sepanjang jalan berpindah masuk ke dalam PLG pada siang atau sore hari dan pada saat hari libur karena pada saat itu wisatawan mulai ramai. Menurut penelitian Zairina et al. (2015) di Hutan Rakyat Ambender individu-individu monyet ekor panjang tersebut diketahui berpindah-pindah pada lokasi yang berbeda pada hari yang sama.

\section{KESIMPULAN DAN SARAN}

Lima kelompok monyet ekor panjang ditemukan di sepanjang jalan yang menghubungkan Plang Hijau dengan PLG Taman Nasional Way Kambas yang secara geografis terpisah satu sama lain. Titik kelompok A berada pada distribusi area 225,1 m², B 224,5 m², C $160 \mathrm{~m}^{2}$, D 245 $\mathrm{m}^{2}$, dan $\mathrm{E} 402,9 \mathrm{~m}^{2}$. Tiga kelompok $(\mathrm{A}, \mathrm{B}, \mathrm{C})$ dari lima kelompok tersebut aktivitasnya terjadi dekat dengan Pintu Masuk PLG. Hal itu menunjukkan bahwa kelompok tersebut dipengaruhi oleh aktivitas wisatawan. Dua kelompok lainnya ( $D$ dan $E$ ) berada pada kondisi habitat yang alami. Persebaran kelompok berdampingan dan dipengaruhi oleh keberadaan sumber air, sumber pakan, luas tempat bermain dan aktivitas wisatawan. Penelitian lanjutan perlu dilakukan untuk mengetahui penyebaran populasi monyet ekor panjang secara berkesinambungan dan menyeluruh di kawasan TNWK.

\section{UCAPAN TERIMA KASIH}

Ucapan terima kasih disampaikan kepada pihak Taman Nasional Way Kambas yang telah memfasilitasi pelaksanaan penelitian ini.

\section{DAFTAR PUSTAKA}

[BTNWK] Balai Taman Nasional Way Kambas. (2016). Rencana Pengelolaan Jangka Panjang Taman Nasional Way Kambas Provinsi Lampung Periode 2017-2026. Labuhan Ratu: Balai Taman Nasional Way Kambas.

Dewi, B. S. (2015). Dung Beetle Satwa, Peyebar Biji Tingkat Kedua. Yogyakarta: Plantaxia.

Djuwantoko., Utami, R.N. \& Wiyono. (2008). Perilaku agresif monyet, Macaca fascicularis (Raffles, 1821) terhadap wisatawan di Hutan Wisata Alam Kaliurang, Yogyakarta. Biodiversitas, 9(4), 301-305.

Fakhri, K., Priyono, B., Rahayuningsih, M. (2012). Studi awal populasi dan distribusi Macaca fascicularis Ulolanang. Unnes Journal of Life Science, 1(2), 1-7. 
Febrianti, D., \& Dewi, B.S. (2010). Studi Prilaku Harian Kelompok Monyet Ekor Panjang (Macaca fascicularis) di Pulau Condong Darat Desa Rangai Kecamatan Ketibung Kabupaten Lampung Selatan. [Skripsi]. Bandar Lampung: Jurusan Menejemen Hutan, Fakultas Pertanian, Universitas Lampung. Tidak Dipublikasikan.

Hidayat, A. A. (2016). Struktur kelompok monyet ekor panjang (Macaca fascicularis Raffles, 1821) dan interaksinya dengan penduduk sekitar Suaka Margasatwa Paliyan. Jurnal Biologi, 5(8), 19-27.

Pramudya, A., Setiawan, A. \& Rustiati, E. L. (2015). Ukuran kelompok monyet ekor panjang (Macaca fascicularis) di Hutan Desa Cugung Kesatuan Pengelolaan Hutan Lindung Gunung Rajabasa Lampung Selatan. Jurnal Sylva Lestari, 3(3),107-112.

Risdiyansyah, Harianto, S. P. \& Nurcahyani, N. (2014). Studi populasi monyet ekor panjang (Macaca Fascicularis) di Pulau Condong Darat Desa Rangai Kecamatan Ketibung Kabupaten Lampung Selatan. Jurnal Sylva Lestari, 2(1), 41-48.

Santoso, N. (1996). Analisis habitat dan potensi pakan monyet ekor panjang di Pulau Tinjil. Jurnal Media Konservasi, 5(1), 5-9.

Seponada \& Firman. (2010). Hutan Monyet Lembah Sarijo. 29 Oktober 2017, diunduh dari http://wisata.kompasiana.com/jalan-jalan/2010/04/25/hutan-monyet-lembah-sarijo/.

Sembiring, R.P., Setiawan, A. \& Darmawan, A. (2016). Penyebaran dan kelimpahan populasi monyet ekor panjang (Macaca fascicularis) di Cagar Alam Sibolangit. Jurnal Sylva Lestari, 4(3), 47-58.

Zairina, A., Yanuwiadi, B. \& Indriyani, S. (2015). Pola penyebaran harian dan karakteristik tumbuhan pakan monyet ekor panjang (Macaca fascicularis R.) di Hutan Rakyat Ambender, Pamekasan, Madura. J-PAL, 6(1), 21-27. 